\title{
Grazing-Induced Modifications to Peak Standing Crop in Northern Mixed-Grass Prairie
}

\author{
Justin D. Derner ${ }^{1}$ and Richard H. Hart ${ }^{2}$ \\ Authors are ${ }^{1}$ Rangeland Scientist and ${ }^{2}$ Rangeland Scientist (retired), US Department of Agriculture, Agricultural Research Service, High Plains Grasslands \\ Research Station, 8408 Hildreth Rd, Cheyenne, WY 82009.
}

\begin{abstract}
Selective grazing can modify the productive capacity of rangelands by reducing competitiveness of productive, palatable species and increasing the composition of more grazing-resistant species. A grazing system (season-long and short-duration rotational grazing) $\times$ stocking rate (light: 16 steers $\cdot 80 \mathrm{ha}^{-1}$, moderate: 4 steers $\cdot 12 \mathrm{ha}^{-1}$, and heavy: 4 steers $\cdot 9 \mathrm{ha}^{-1}$ ) study was initiated in 1982 on northern mixed-grass prairie. Here, we report on the final 16 years of this study (1991-2006). Spring (April + May + June) precipitation explained at least $54 \%$ of the variation in peak standing crop. The percentage of variation explained by spring precipitation was similar between stocking rates with short-duration grazing but decreased with increasing stocking rate for season-long grazing. April precipitation explained the greatest percentage of the variation in peak standing crop for the light stocking rate (45\%), May precipitation for the moderate stocking rate (49\%), and June precipitation for the heavy stocking rate $(34 \%)$. Peak standing crop was $23 \%-29 \%$ greater with light $\left(1495 \pm 66 \mathrm{~kg} \cdot \mathrm{ha}^{-1}\right.$, mean \pm 1 SE) compared to moderate $\left(1218 \pm 64 \mathrm{~kg} \cdot \mathrm{ha}^{-1}\right)$ and heavy $\left(1156 \pm 56 \mathrm{~kg} \cdot \mathrm{ha}^{-1}\right)$ stocking rates, which did not differ. Differences in peak standing crop among stocking rates occurred during average and wet but not dry springs. Neither the interaction of grazing system and stocking rate nor grazing system alone affected standing crop across all years or dry, average, or wet springs. Grazing-induced modification of productive capacity in this northern mixed-grass prairie is attributed to changes in species composition with increasing stocking rate as the less productive, warm-season shortgrass blue grama (Bouteloua gracilis [H.B.K.] Lag. ex Griffiths) increases at the expense of more productive, cool-season midheight grasses. Land managers may need to substantially modify management to offset these losses in productive capacity.
\end{abstract}

\section{Resumen}

El apacentamiento selectivo puede modificar la capacidad productiva de los pastizales al reducir la competitividad de las especies productivas y apetecibles e incrementar la composición de especies más resistentes al apacentamiento. En 1982 se inició un estudio en las praderas de zacates mixtos del norte, en el que se evaluó un sistema de apacentamiento (continuo y rotacional de corta duración) en combinación con cargas animal (ligera 16 novillos $\cdot 80 \mathrm{ha}^{-1}$, moderado 4 novillos $\cdot 12 \mathrm{ha}^{-1}$, y alta 4 novillos $\left.\cdot 9 \mathrm{ha}^{-1}\right)$. Aquí, reportamos el final de este estudio de 16 años (1991-2006). La precipitación de primavera (abril + mayo + junio) explicó al menos $54 \%$ de la variación de la producción pico de la biomasa en pie El porcentaje de variación explicado por la precipitación de primavera, fue similar entre cargas animal en el apacentamiento de corta duración, pero disminuyó al incrementar la carga animal en el sistema de apacentamiento continuo. La precipitación de abril explicó el mayor porcentaje de la variación del pico de producción de la biomasa en pie en la carga animal ligera $(45 \%)$, la precipitación de mayo para la carga animal moderada (49\%), y la de junio para la carga pesada $(34 \%)$. El pico de la biomasa en pie fue $23 \%-$ $29 \%$ mayor con la carga ligera $\left(1495 \pm 66 \mathrm{~kg} \cdot \mathrm{ha}^{-1}\right.$, media $\left.\pm 1 \mathrm{DE}\right)$ en comparación con las cargas moderada $\left(1218 \pm 64 \mathrm{~kg} \cdot \mathrm{ha}^{-1}\right)$ y alta $\left(1156 \pm 56 \mathrm{~kg} \cdot \mathrm{ha}^{-1}\right)$, las cuales no fueron diferentes. En primaveras con lluvia promedio o superior a este, se registraron diferencias entre cargas animal en el pico de la biomasa en pie y lo que no ocurrió en las primaveras secas. Ni la interacción entre sistema de apacentamiento y carga animal, ni el sistema de apacentamiento solo afectó la biomasa a través de todos los años, o en las primaveras secas, promedio o húmedas. La modificación inducida por el apacentamiento en la capacidad productiva de esta pradera de zacates mixtos del norte, es atribuida a cambios en la composición de especies al incrementar la carga animal; ya que zacates menos productivos, como el zacate de verano "Blue grama" (Bouteloua gracilis [H.B.K.] Lag. ex Griffiths), aumentan a expensas de los zacates medianos de invierno más productivos. Los manejadores pueden necesitar modificar substancialmente el manejo para sobreponer estas pérdidas de la capacidad productiva.

Key Words: continuous grazing, grazing system, rotational grazing, short-duration grazing, spring precipitation, stocking rate

\section{INTRODUCTION}

The USDA-ARS, Northern Plains Area, is an equal opportunity/affirmative action employer and all agency services are available without discrimination.

Correspondence: Justin Derner, USDA-ARS, High Plains Grasslands Research Station, 8408 Hildreth Rd, Cheyenne, WY 82009. Email: Justin.Derner@ars.usda.gov

Manuscript received 21 April 2006; manuscript accepted 2 March 2007.
At global (Lauenroth 1979), regional (Sala et al. 1988; Lauenroth et al. 1999), and individual site (Lauenroth and Sala 1992; Smart et al. 2007) scales, peak standing crop in semiarid rangelands is influenced largely by precipitation. Regression relationships have been developed for predicting peak standing crop from precipitation in many rangeland ecosystems (Milchunas et al. 1994; O’Connor et al. 2001; 
Khumalo and Holechek 2005), and annual precipitation and peak standing crop were highly correlated (0.88) for 19 sites encompassing a shortgrass steppe to tallgrass prairie gradient in the Great Plains (Barrett et al. 2002). The productive capacity of northern mixed-grass prairie is influenced largely by spring precipitation because of dominance by the perennial coolseason midheight grasses western wheatgrass (Pascopyrum smithii [Rydb] A. Love) and needle-and-thread (Hesperostipa comata [Trin. \& Rupr.] Barkworth) (Biondini and Manske 1996). Several regression relationships have been developed for predicting peak standing crop from spring precipitation in this rangeland ecosystem (Hart and Samuel 1985; Biondini and Manske 1996; Biondini et al. 1998; Heitschmidt et al. 1999; Andales et al. 2006). These studies, however, have not addressed long-term grazing-induced modifications to plant communities in the northern mixed-grass prairie through the decrease of perennial cool-season grasses and the resulting increase of perennial warm-season shortgrasses with increasing stocking rate (Manley et al. 1997). Subsequently, these modifications may influence the predictive ability of spring precipitation to estimate peak standing crop (Smart et al. 2007).

Although stocking rate is the primary management driving factor influencing vegetation responses in rangeland ecosystems (Manley et al. 1997; Rogers et al. 2005), short-duration rotational grazing has been extensively used in rangeland ecosystems with the objective of reducing the selectivity of grazing animals (i.e., patch grazing) that occurs with seasonlong grazing under low to moderate stocking rates (Teague and Dowhower 2003). This grazing system provides short times of concentrated grazing activity and longer times of recovery by moving livestock through a series of small paddocks, thereby providing greater managerial control over the frequency (but see Hart et al. 1993a) and uniformity but not intensity of defoliation (Gillen et al. 1990; Heitschmidt et al. 1990; Derner et al. 1994). However, most studies in the northern mixed-grass prairie have concluded that vegetation is largely nonresponsive to short-duration rotational grazing (Kirby and Webb 1986; Hart et al. 1988, 1993b; Hepworth et al. 1991; Biondini and Manske 1996; Manley et al. 1997).

Our objective in this study was to assess grazing-induced modifications to current-year peak standing crop of northern mixed-grass prairie. This study takes advantage of a longterm experiment in southeastern Wyoming in which peak standing crop data have been collected since 1982 (Hart et al. 1988; Manley et al. 1997). Here, we report on the final 16 years of this study (1991-2006). Our specific objectives were: 1) to determine relationships between spring precipitation and peak standing crop in pastures with long-term stocking rate and grazing system treatments and determine the influence of 2) stocking rate, 3) grazing system, and 4) stocking rate $\times$ grazing system interactions on peak standing crop of northern mixed-grass prairie. We hypothesized that: 1) more variation in peak standing crop would be explained by spring precipitation with light compared to heavier stocking rates, as the light stocking rate has maintained a greater composition of perennial, cool-season grasses; 2) stocking rate but not grazing system will influence peak standing crop; and 3) effects of stocking rate on peak standing crop will be evident only when spring precipitation is average to above average, as soil water limitations override stocking rate in dry years.

\section{MATERIALS AND METHODS}

\section{Site Description}

An experiment was initiated in 1982 on northern mixed-grass prairie at the USDA-Agricultural Research Service High Plains Grasslands Research Station, approximately $7 \mathrm{~km}$ northwest of Cheyenne, Wyoming (lat $41^{\circ} 11^{\prime} \mathrm{N}$, long $104^{\circ} 53^{\prime} \mathrm{W}$ ). Mean annual precipitation (132 years) is $381 \mathrm{~mm}$ with a peak in May. Soils are coarse and well drained, comprised mainly of Albinas, Ascalon, and Altvan loams (mixed mesic Aridic Agriustolls) and Cascajo gravelly loam (mixed mesic Aridic Calciorthid) (Stevenson et al. 1984). Vegetation is mainly grasses. Perennial cool-season graminoids include western wheatgrass, needle-and-thread, prairie junegrass (Koeleria macrantha [Ledeb.] J.A. Schultes), and needleleaf sedge (Carex duriuscula C.A. Mey). Blue grama (Bouteloua gracilis [H.B.K.] Lag. ex Griffiths) is the primary perennial warm-season grass, scarlet globemallow (Sphaeralcea coccinea [Nutt.] Rydb.) is the primary forb, and fringed sage (Artemisia frigida Willd.) is the primary subshrub. Warm-season grasses and forbs increase and cool-season grasses decrease with heavy stocking rates at this site (Manley et al. 1997).

\section{Grazing Treatments}

In 1982, 2 grazing systems were initiated using a randomized block design on the study area that had previously been grazed very lightly by livestock and wildlife: 1 ) season-long continuous grazing, and 2) short-duration rotational grazing having 8 paddocks with 4 grazing cycles of approximately 2-, 3-, 5-, and 7-day grazing periods. All pastures were grazed for approximately 130 days (mid-June to mid-October) with yearling steers. Three stocking rates were applied to the season-long grazed pastures: light (16 steers $\cdot 80 \mathrm{ha}^{-1}$, about $35 \%$ below NRCS-recommended rate), moderate (4 steers $\cdot 12 \mathrm{ha}^{-1}$, the NRSC-recommended rate), and heavy (4 steers $\cdot 9 \mathrm{ha}^{-1}, 33 \%$ greater than the NRCS-recommended rate) (Hart et al. 1988). Moderate and heavy stocking rates were used for shortduration rotational grazing. Two pastures were used for each stocking rate $\times$ grazing system combination with the exception of the lightly stocked, season-long grazed treatment because of limitations with the original pasture layout.

\section{Peak Standing Crop}

In late July/early August each year, with the exception of 2000, peak standing crop was determined inside 4 (1991-2003) or 6 (2004-2006) $1.5-\mathrm{m}^{2}$ exclosures for each season-long grazed pasture. In addition, a total of 4 or 6 exclosures were randomly located across the 8 paddocks in each short-duration rotational grazing pasture. Peak standing crop was hand clipped from a $0.18-\mathrm{m}^{2}$ quadrat to ground level in each exclosure or estimated using a capacitance meter reading that was converted to a peak standing crop value from a regression equation (Manley et al. 1997). Total current year plant biomass was separated from older biomass, dried at $60^{\circ} \mathrm{C}$, and weighed. Exclosures were moved a random distance in a random 
Table 1. April, May, June, and annual precipitation $(\mathrm{mm})$ at the High Plains Grasslands Research Station, near Cheyenne, Wyoming (19912006).

\begin{tabular}{lrrrrcc}
\hline Year & April & \multicolumn{1}{c}{ May } & \multicolumn{1}{c}{ June } & $\mathrm{A}+\mathrm{M}+\mathrm{J}$ & Classification $^{1}$ & Annual \\
\hline 1991 & 28.5 & 113.1 & 114.7 & 256.3 & Wet & 513.5 \\
1992 & 11.1 & 46.1 & 66.6 & 123.8 & Average & 396.0 \\
1993 & 61.1 & 38.7 & 96.3 & 196.1 & Average & 492.7 \\
1994 & 40.2 & 42.5 & 16.7 & 99.4 & Average & 306.4 \\
1995 & 39.6 & 189.2 & 101.1 & 329.9 & Wet & 575.3 \\
1996 & 39.5 & 70.9 & 46.5 & 156.9 & Average & 393.3 \\
1997 & 38.3 & 85.6 & 82.4 & 206.3 & Average & 578.4 \\
1998 & 36.1 & 86.9 & 53.5 & 176.5 & Average & 315.3 \\
1999 & 170.0 & 54.4 & 36.7 & 264.1 & Wet & 432.8 \\
2000 & 13.0 & 37.6 & 13.6 & 64.2 & Dry & 303.5 \\
2001 & 59.8 & 63.2 & 31.4 & 154.4 & Average & 302.7 \\
2002 & 6.0 & 16.2 & 20.2 & 42.4 & Dry & 204.4 \\
2003 & 53.5 & 27.6 & 79.5 & 160.6 & Average & 345.2 \\
2004 & 33.3 & 27.6 & 69.6 & 130.5 & Average & 359.2 \\
2005 & 34.3 & 24.9 & 125.5 & 184.7 & Average & 379.5 \\
2006 & 22.4 & 35.8 & 11.6 & 69.8 & Dry & \\
$1991-2006$ & 42.9 & 60.0 & 60.4 & 163.3 & & 393.2 \\
mean & & & & & &
\end{tabular}

1Dry: April + May + June total < 1991-2006 mean - 1 SD; average: April + May + June total within range of 1991-2006 mean \pm 1 SD; wet: April + May + June total $>1991-$ 2006 mean +1 SD

cardinal direction each year prior to the grazing season but remained on similar slope and soil series.

\section{Statistical Analyses}

Relationships between peak standing crop and April, May, and June monthly precipitation and all possible combinations of these months, were fit with linear, power, and hyperbolic functions using SigmaPlot 2000 (SPSS Inc., Chicago, IL). The model with the greatest $r^{2}$ value was used as the best fit (Derner et al. 2004). To determine the influence of stocking rate on peak standing crop, we limited grazing treatments to only the season-long grazing system and initially analyzed data using analysis of variance (ANOVA; SAS Institute Inc. 1999) with stocking rate (light, moderate, and heavy) as the single factor. To further investigate the influence of stocking rate on peak standing crop, we classified years as average if precipitation during April-June was within the mean \pm 1 SD of the 16-year record, dry if less than the mean $\pm 1 \mathrm{SD}$, and wet if greater than the mean \pm 1 SD (Table 1) and used a 1-factor ANOVA to analyze peak standing crop within each classification. To determine the influence of grazing system and grazing system $\times$ stocking rate interaction on peak standing crop, we used the season-long and short-duration rotational grazing systems with moderate and heavy stocking rates. A 2-factor ANOVA was used with stocking rate (moderate and heavy) and grazing system (season-long and short-duration rotational). To determine if spring precipitation affected our findings, we classified spring precipitation as previously described and conducted a 2-factor ANOVA (grazing system and stocking rate) within each dry, average, and wet spring classification. The alpha level of 0.10 rather than 0.05 was used in all

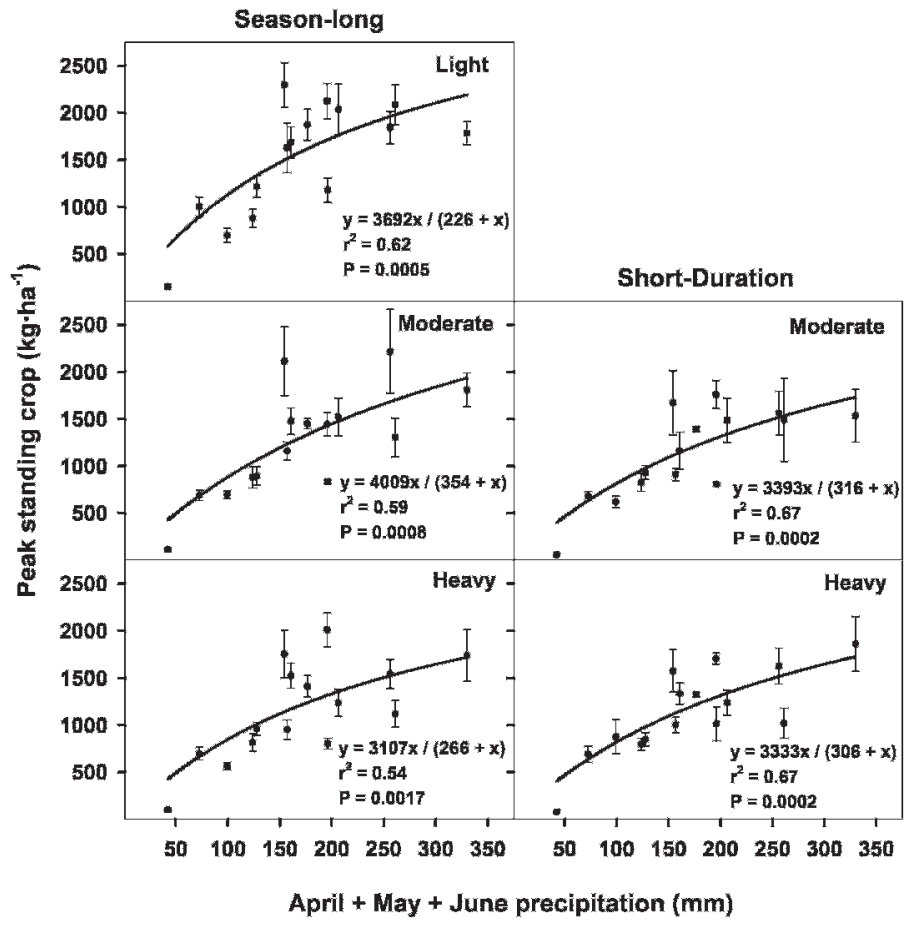

Figure 1. Hyperbolic relationships between peak standing crop $\left(\mathrm{kg} \cdot \mathrm{ha}^{-1}\right.$, mean $\left.\pm 1 \mathrm{SE}\right)$ and April + May + June spring precipitation $(\mathrm{mm})$ for season-long grazing at light (16 steers $\left.\cdot 80 \mathrm{ha}^{-1}\right)$, moderate (4 steers $\cdot 12 \mathrm{ha}^{-1}$ ), and heavy (4 steers $\cdot 9 \mathrm{ha}^{-1}$ ) stocking rates and for short-duration 8-paddock rotational grazing at moderate and heavy stocking rates on northern mixed-grass prairie at the High Plains Grasslands Research Station near Cheyenne, Wyoming (1991-2006).

comparisons to determine significance because of limited replication.

\section{RESULTS}

\section{Spring Precipitation}

April, May, and June precipitation amounts varied considerably from 1991 to 2006. For example, April + May + June precipitation exhibited an 8 -fold difference from the lowest (42.4 $\mathrm{mm}$ in 2002) to the highest (329.9 $\mathrm{mm}$ in 1995) value (Table 1). Ten of the 16 springs were classified as average using the criterion of spring precipitation being within $\pm 1 \mathrm{SD}$ of the 16-year mean. Three springs each were classified as wet $(>1$ SD) and dry $(<1 \mathrm{SD})$. Annual precipitation was also quite variable with an almost 3 -fold difference between the driest (204 $\mathrm{mm}$ in 2002) and wettest (578 $\mathrm{mm}$ in 1997) years.

\section{Relationship Between Spring Precipitation and Peak Standing Crop}

April + May + June precipitation explained at least $54 \%$ of the variation in peak standing crop for pastures with long-term stocking rate and grazing system treatments (Fig. 1). The percentage of variation in peak standing crop explained by spring precipitation was similar between stocking rates with short-duration grazing, but it did decrease with increasing stocking rate for season-long grazing. April precipitation explained the greatest percentage of the variation in peak 


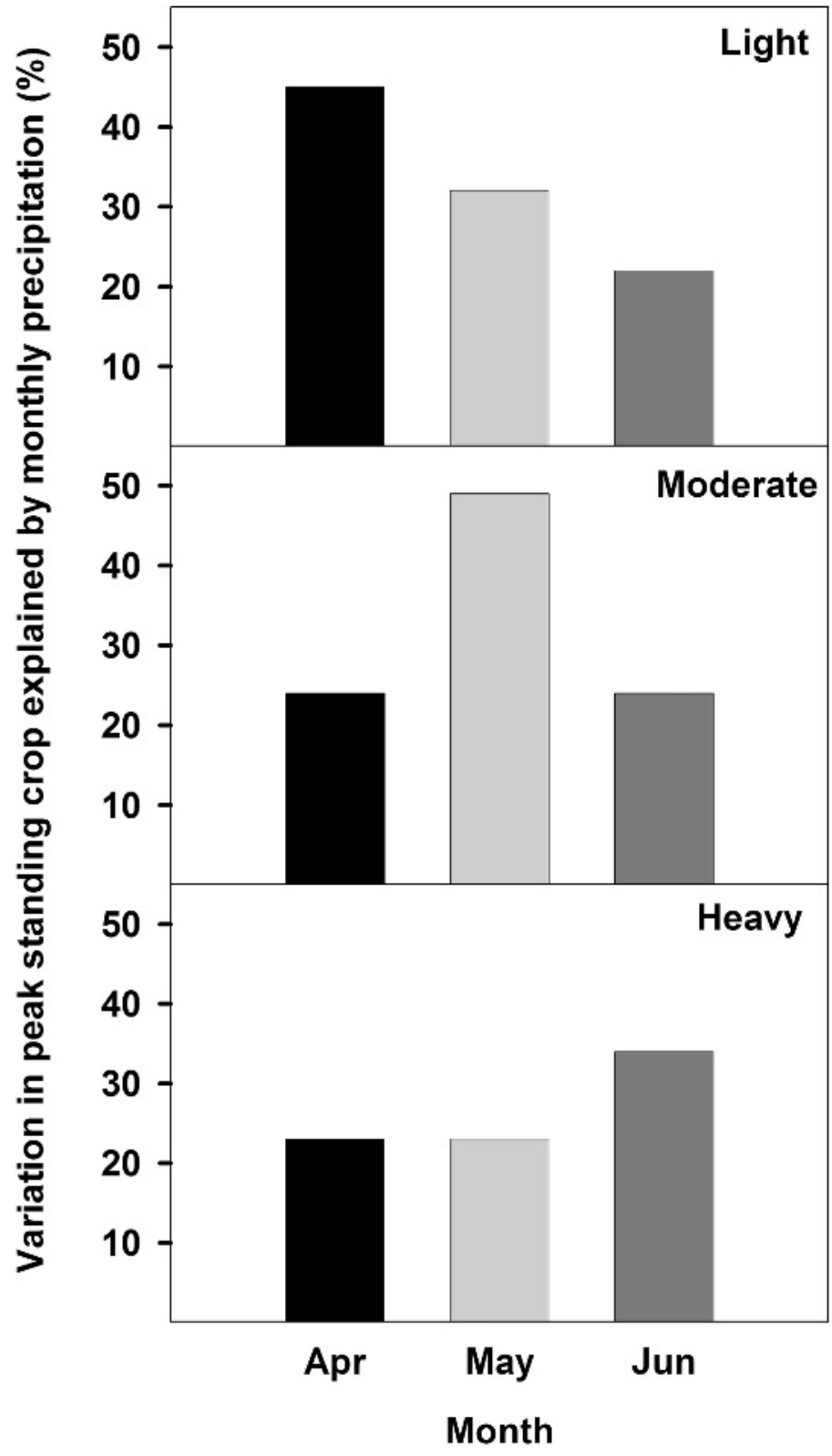

Figure 2. Variation in peak standing crop $\left(r^{2}\right)$ explained by April, May, and June precipitation $(\mathrm{mm})$ for season-long grazing at light (16 steers $\left.\cdot 80 \mathrm{ha}^{-1}\right)$, moderate (4 steers $\cdot 12 \mathrm{ha}^{-1}$ ), and heavy (4 steers $\cdot 9 \mathrm{ha}^{-1}$ ) stocking rates on northern mixed-grass prairie at the High Plains Grasslands Research Station near Cheyenne, Wyoming (1991-2006).

standing crop for season-long grazing at the light stocking rate $(45 \%)$, May precipitation for the moderate stocking rate $(49 \%)$, and June precipitation for the heavy stocking rate (34\%) (Fig. 2).

\section{Stocking Rate}

Peak standing crop was $23 \%-29 \%$ greater $(P=0.0002)$ with light $\left(1495 \pm 66 \mathrm{~kg} \cdot \mathrm{ha}^{-1}\right)$ compared to moderate (1 218 $\left.\pm 64 \mathrm{~kg} \cdot \mathrm{ha}^{-1}\right)$ and heavy $\left(1156 \pm 56 \mathrm{~kg} \cdot \mathrm{ha}^{-1}\right)$ stocking rates, which did not differ, in season-long grazed pastures across the 16 years (1991-2006) (Fig. 3). Differences in peak standing crop among stocking rates occurred during average

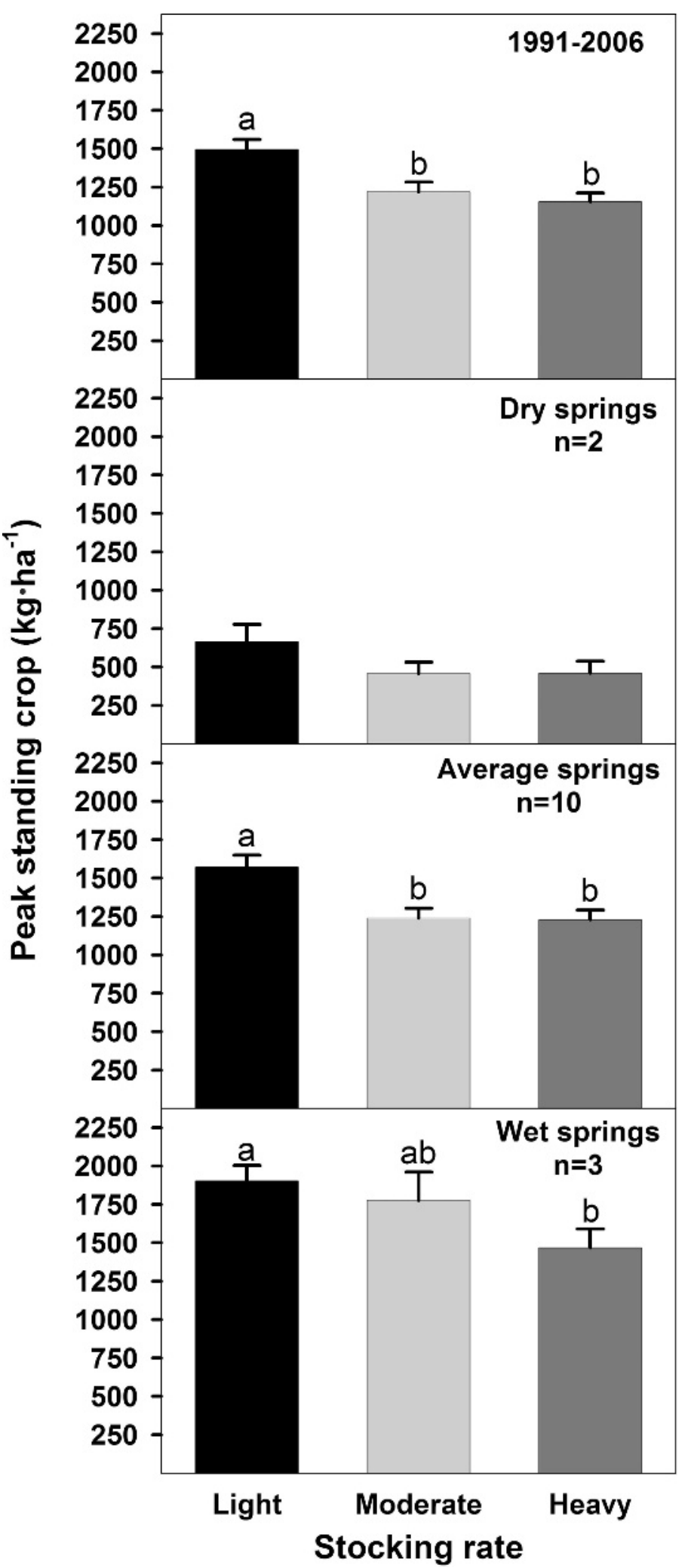

Figure 3. Peak standing crop $\left(\mathrm{kg} \cdot \mathrm{ha}^{-1}\right.$, mean $\left.\pm 1 \mathrm{SE}\right)$ for light (16 steers $\left.\cdot 80 \mathrm{ha}^{-1}\right)$, moderate (4 steers $\left.\cdot 12 \mathrm{ha}^{-1}\right)$, and heavy (4 steers $\cdot 9 \mathrm{ha}^{-1}$ ) stocking rates with season-long grazing on northern mixed-grass prairie at the High Plains Grasslands Research Station, near Cheyenne, Wyoming, for the 1991-2006 study years and for dry, average, and wet springs during this period. Letters indicate significant $(P<0.10)$ differences between stocking rates. Data not collected in 2000. 
$(P=0.0004)$ and wet $(P=0.0828)$ but not dry $(P=0.1856)$ springs.

\section{Grazing System and Stocking Rate}

Grazing system and stocking rate did not interact to influence standing crop across all years $(1991-2006)(P=0.4247)$ or dry $(P=0.6149)$, average $(P=0.6051)$, or wet $(P=0.3869)$ springs (Fig. 4). Nor did grazing system affect peak standing crop for all years $(P=0.2013)$ or dry $(P=0.7454)$, average $(P=0.1896)$, and wet $(P=0.5181)$ springs.

\section{DISCUSSION}

Livestock grazing has induced modifications to peak standing crop in this northern mixed-grass prairie through stocking rate but not grazing system. More variation in peak standing crop was explained by earlier (April) spring precipitation for light stocking rates, but later (June) spring precipitation explained more variation for the heavy stocking rates. This finding is attributed to the maintenance of a higher composition of perennial, cool-season grasses with light stocking (Manley et al. 1997) and the ability of this plant community to express greater peak standing crop with high amounts of spring precipitation. Milchunas et al. (1994) found that the variability in forage production was explained mostly by spring precipitation in shortgrass steppe and that production per unit increase in precipitation was greater for spring than summer precipitation, but only when spring precipitation was above average. Peak standing crop was $23 \%-29 \%$ greater with light compared to moderate and heavy stocking rates with differences occurring in springs with wet and average precipitation. Conversely, no differences among stocking rates were observed in dry springs, suggesting that constraints of soil water limited expression of productive potential in these years.

Spring precipitation has been used to develop predictive estimations of peak standing crop in the northern mixed-grass prairie (Hart and Samuel 1985; Biondini and Manske 1996; Biondini et al. 1998; Heitschmidt et al. 1999; Andales et al. 2006; Smart et al. 2007), with predictive ability more robust for ecological sites with sandy subsoils that have lower water storage capacity than for sites with loamy subsoils that have a greater water storage capacity (Hart and Samuel 1985). Lauenroth and Whitman (1977) determined that precipitation explained only $5 \%$ of the variability in aboveground biomass from a single year of production data in a mixed-grass prairie in western North Dakota. They determined that air temperature, vapor pressure deficit, and soil temperature explained $99 \%$ of the variability in aboveground biomass. Discrepancies between our findings and those of Lauenroth and Whitman (1977) emphasize the functionality of long-term data to discern trends across a range of environmental conditions such that land managers have strategic utility of using spring precipitation to predict peak standing crop with a reasonable level of confidence. Tactical predictive ability of estimating peak standing crop within a single year merits inclusion of additional variable input (e.g., soil moisture, seasonal weather forecasts) to increase robustness of predictions (Andales et al. 2006). Nevertheless, these long-term data in the northern mixed-grass prairie provide regression equations for peak standing crop at

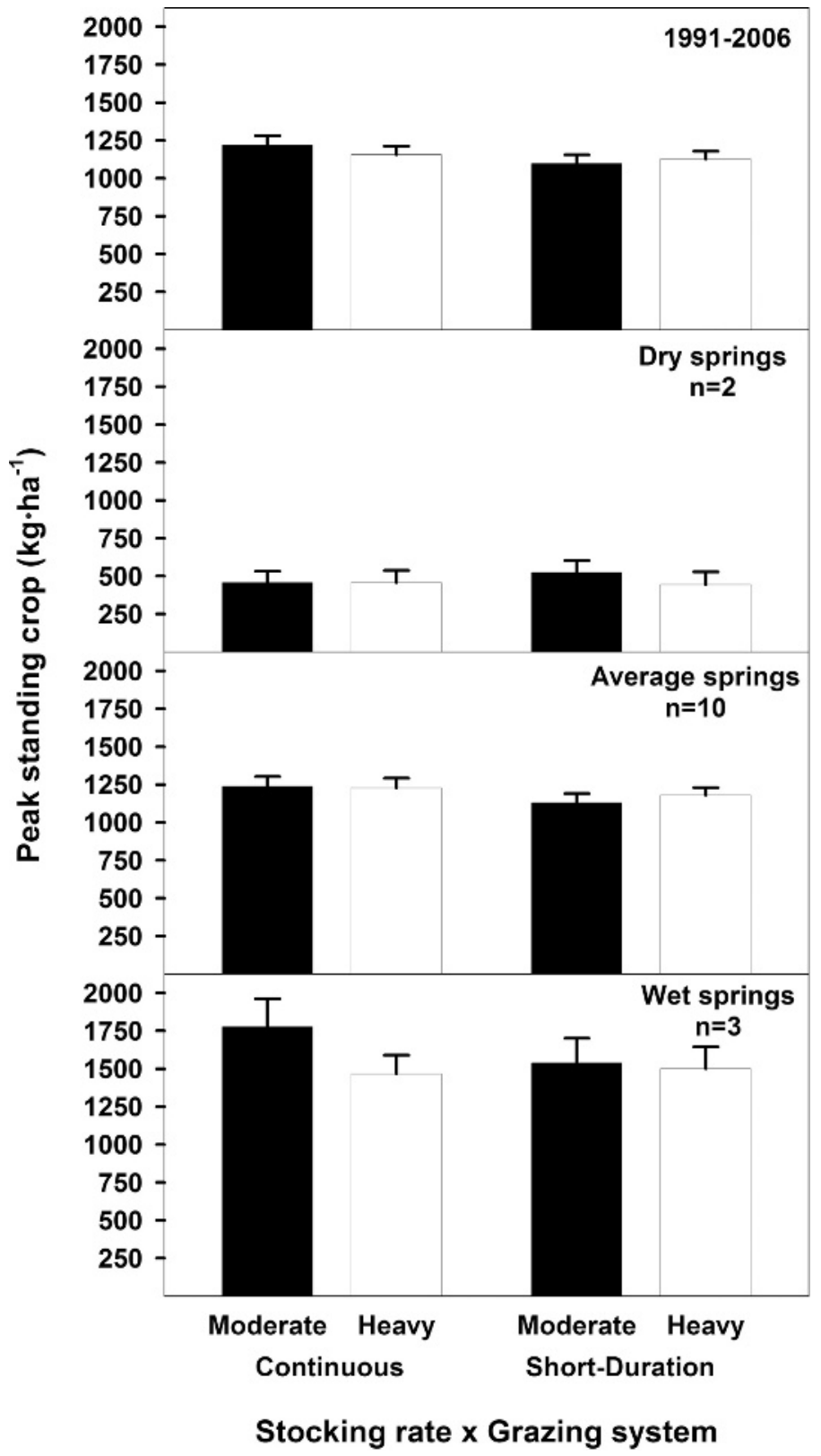

Figure 4. Peak standing crop $\left(\mathrm{kg} \cdot \mathrm{ha}^{-1}\right.$, mean $\left.\pm 1 \mathrm{SE}\right)$ for seasonlong and short-duration 8-paddock rotational grazing systems at moderate (4 steers $\cdot 12 \mathrm{ha}^{-1}$ ) and heavy (4 steers $\cdot 9 \mathrm{ha}^{-1}$ ) stocking rates on northern mixed-grass prairie at the High Plains Grasslands Research Station, near Cheyenne, Wyoming, for the 1991-2006 study years and for dry, average, and wet springs during this period. Data not collected in 2000 .

light, moderate, and heavy stocking rates that can be used by land managers to determine carrying capacity of their management units.

Milchunas and Lauenroth (1993) concluded, for a global range of environments, that most effects of grazing on aboveground net primary production were negative. For example, standing crop decreased with increasing stocking rate in tallgrass prairie (Cassels et al. 1995) and shortgrass steppe (Milchunas et al. 1994), and standing crop was inversely proportional to stocking rate in southern mixed- 
grass prairie (Ralphs et al. 1990). We observed a substantial increase $(23 \%-29 \%)$ in peak standing crop with light stocking compared to moderate and heavy stocking rates, which is similar to findings of Rogers et al. (2005) in northern mixed-grass prairie. This difference was not demonstrated in the 2 previous studies at this site, as Hart et al. (1988) did not include data from the lightly stocked, season-long grazing treatment because peak standing crop was not collected until 1991, and Manley et al. (1997) had only 4 years of data for comparisons among the 3 stocking rates. Our findings in the northern mixed-grass prairie concur with those of Hart and Ashby (1998) in shortgrass steppe where peak standing crop was greater with light stocking rates compared to moderate and heavy stocking rates, which did not differ after 55 years of treatments.

There is a clear need for long-term experimental analyses of plant community responses to grazing, as vegetation responses develop over a long time (Bullock et al. 2001) and grazing effects on productivity are affected by patch size with defoliation having neutral to positive effects on intermediate and large patches and negative effects on very small patches (Semmartin and Oesterheld 1996). Selective herbivory of coolseason perennial grasses in the northern mixed-grass prairie (Hart et al. 1993a), which are the late-seral dominant plants, is the dominant mechanism contributing to species replacement (Anderson and Briske 1995) and often leads to reductions in carrying capacity (Ellison 1960). Because the shortgrass blue grama is less productive than the cool-season midheight grasses and blue grama increases with increasing stocking rates (e.g., Manley et al. 1997), productive capacity of the northern mixed-grass prairie is reduced (Smart et al. 2007). In contrast, greater peak standing crop with light compared to moderate and heavy stocking rates is attributable to the maintenance of productive potential of the dominant cool-season perennial grasses. Grazing-induced changes in vegetation composition of northern mixed-grass prairie with increasing stocking rate (e.g., Manley et al. 1997) not only affect ecosystem structure by changing a midheight grass community to a shortgrass-dominated community but also affect ecosystem function, as soil carbon storage is more vulnerable to losses associated with drought periods under heavy compared to light stocking rates (Schuman et al. 2005). In addition to stocking rate establishing long-term directional changes in vegetation composition, episodic climatic events (e.g., drought) define the short-term rate and trajectory of change in semiarid rangeland ecosystems (Fuhlendorf et al. 2001).

The lack of a peak standing crop response to grazing system and absence of grazing system by stocking rate interactions in this study are consistent with previous findings from the earlier years of this study (Hart et al. 1988; Manley et al. 1997). Biondini and Manske (1996) also found no differences in aboveground biomass between rotational and season-long grazing in northern mixed-grass prairie in North Dakota. In addition, our findings are in agreement with those from other rangeland ecosystems. Peak standing crop of tallgrass prairie did not differ between season-long and short-duration rotational grazing systems across a range of stocking rates, and grazing system did not interact with stocking rate (Cassels et al. 1995). Standing crop of grass was similar between rotational grazing and season-long grazing in southern mixed-grass prairie (Wood and Blackburn 1984), and total herbage was similar between season-long and rotational grazing in New Mexico shortgrass prairie (White et al. 1991). Heitschmidt et al. (1987) found greater herbaceous standing crop with seasonlong grazing compared to rotational grazing in southern mixedgrass prairie, but this difference was due to greater amounts of senesced rather than live forage.

\section{MANAGEMENT IMPLICATIONS}

Developed relationships between spring precipitation and peak standing crop for stocking rates and grazing systems have utility for strategic planning efforts by land managers. For example, the STEERISK spreadsheet can be used to calculate the most profitable stocking rate for a given level of peak standing crop estimated from April-May precipitation (Hart 1991). Relationships between spring precipitation and peak standing crop can be used to further develop systems models that will assess production risks in semiarid rangeland ecosystems (Andales et al. 2006).

This long-term study illustrates the importance of stocking rate affecting current year peak standing crop of the northern mixed-grass prairie. The lack of a grazing system effect on peak standing crop is consistent with previous findings from this study site (Hart et al. 1988; Manley et al. 1997) and may be attributable to the range of stocking rates used in this study. Grazing-induced modification of this rangeland ecosystem has fundamental implications to land managers, as vegetative productivity was $19 \%-23 \%$ less with moderate to heavy compared to light stocking rates. This decline in productivity is largely a result of replacement of cool-season perennial grasses by less productive, warm-season perennial shortgrasses. As a result of this diminished carrying capacity in pastures under moderate to heavy stocking rates, land managers who do not adjust their stocking rates to account for reduced production are imposing grazing pressures higher than sustainable for the lower-yielding plant communities. As such, this likely results in a negative feedback loop whereby grazing at higher-than-intended grazing pressures exacerbates vegetation changes from a northern mixed-grass prairie to a community more characteristic of the shortgrass steppe with increasing dominance of blue grama. Structural and functional changes (Schuman et al. 2005) associated with moderate and heavy stocking rates likely alter the vegetation state of the plant community and may require substantial modifications in management to transition the plant community back to a vegetation state dominated by midheight perennial coolseason grasses.

\section{ACKNOWLEDGMENTS}

Mary Ashby, Stanley Clapp, Erica East, Pam Freeman, Tammy Kanode, Jessica Parks, Troy Smith, Jeff Thomas, Ashley Whitman, and numerous student workers collected vegetation data at the High Plains Grasslands Research Station. Matt Mortenson conducted the statistical analyses and prepared figures and tables. We appreciate the insightful review comments from Don Kirby, Sandy Smart, Lance Vermeire, and 2 anonymous reviews. 


\section{LITERATURE CITED}

Andales, A. A., J. D. Derner, L. R. Ahuja, and R. H. Hart. 2006. Strategic and tactical prediction of forage production in northern mixed-grass prairie. Rangeland Ecology \& Management 59:576-584.

Anderson, V. J., AND D. D. Briske. 1995. Herbivore-induced species replacement in grasslands: is it driven by herbivory tolerance or avoidance? Ecological Applications 5:1014-1024.

Barrett, J. E., R. L. McCulley, D. R. Lane, I. C. Burke, and W. K. Lauenroth. 2002. Influence of climate variability on plant production and $\mathrm{N}$-mineralization in central US grasslands. Journal of Vegetation Science 13:383-394.

BIondinI, M. E., AND L. MAnSKE. 1996. Grazing frequency and ecosystem processes in a northern mixed prairie, USA. Ecological Applications 5:239-256.

Biondini, M. E., B. D. Patton, And P. E. Nyren. 1998. Grazing intensity and ecosystem processes in a northern mixed-grass prairie. Ecological Applications 8:469-479.

Bullock, J. M., J. Franklin, M. J. Stevenson, J. Silvertown, S. J. Coulson, S. J. Gregory, AND R. TofTs. 2001. A plant trait analysis of responses to grazing in a long-term experiment. Journal of Applied Ecology 38:253-267.

Cassels, D. M., R. L. Gillen, F. T. McCollum, K. W. Tate, and M. E. Hodges. 1995. Effects of grazing management on standing crop dynamics in tallgrass prairie. Journal of Range Management 48:81-84.

Derner, J. D., R. L. Gilleen, F. T. McCollum, and K. W. Tate. 1994. Little bluestem tiller defoliation patterns under continuous and rotational grazing. Journal of Range Management 47:220-225.

Derner, J. D., H. W. Polley, H. B. Johnson, and C. R. Tischler. 2004. Structural attributes of Schizachyrium scoparium in restored Texas blackland prairies. Restoration Ecology 12:80-84.

Elusson, L. 1960. Influence of grazing on plant succession on rangelands. Botanical Review 26:1-78.

Fuhlendorf, S. D., D. D. Briske, and F. E. Smeins. 2001. Herbaceous vegetation change in variable rangeland environments: the relative contribution of grazing and climatic variability. Applied Vegetation Science 4:177-188.

Gillen, R. L., F. T. McCollum, and J. E. Brummer. 1990. Tiller defoliation patterns under short duration grazing in tallgrass prairie. Journal of Range Management 43:95-99.

HART, R. H. 1991. Managing livestock grazing for risk: the STEERISK spreadsheet. Journal of Range Management 44:227-231.

Hart, R. H., and M. M. Ashby. 1998. Grazing intensities, vegetation, and heifer gains: 55 years on shortgrass. Journal of Range Management 51:392-398.

Hart, R. H., J. Bissio, M. J. Samuel, and J. W. Waggoner, JR. 1993b. Grazing systems, pasture size, and cattle grazing behavior, distribution and gains. Journal of Range Management 46:81-87.

HaRt, R. H., S. ClapP, and P. S. Test. 1993a. Grazing strategies, stocking rates, and frequency and intensity of grazing on western wheatgrass and blue grama. Journal of Range Management 46:122-126.

Hart, R. H., and M. J. Samuel. 1985. Precipitation, soils and herbage production on southeast Wyoming range sites. Journal of Range Management 38:522-525.

Hart, R. H., M. J. Samuel, P. S. Test, and M. A. Smith. 1988. Cattle, vegetation, and economic responses to grazing systems and grazing pressure. Journal of Range Management 41:282-286.

Heitschmidt, R. K., D. D. Briske, And D. L. Price. 1990. Pattern of interspecific tiller defoliation in a mixed-grass prairie grazed by cattle. Grass and Forage Science 45:215-222.

Heitschmidt, R. H., S. L. Dowhower, and J. W. Walker. 1987. Some effects of a rotational grazing treatment on quantity and quality of available forage and amount of ground litter. Journal of Range Management 40:318-321.

Heitschmidt, R. K., M. R. Haferkamp, M. G. Karl, and A. L. Hild. 1999. Drought and grazing: I. Effects of quantity of forage produced. Journal of Range Management 52:440-446.

Hepworth, K. W., P. S. Test, R. H. HaRt, J. W. Waggoner, JR., and M. A. Smith. 1991. Grazing systems, stocking rates, and cattle behavior in southeastern Wyoming. Journal of Range Management 44:259-262.
Khumalo, G., and J. Holechek. 2005. Relationships between Chihuahuan desert perennial grass production and precipitation. Rangeland Ecology \& Management 58:239-246.

KIRBY, D. R., AND H. E. WeBB. 1986. Cattle diets on rotation and seasonlong grazing treatments. North Dakota Farm Research 46:14-17.

LAUENROTH, W. K. 1979. Grassland primary production: North American grasslands in perspective. In: N. R. French [ED.]. Perspectives in grassland ecology. New York, NY: Springer-Verlag. p 3-24.

Lauenroth, W. K., I. C. Burke, and M. P. Gutmann. 1999. The structure and function of ecosystems in the central North American grassland region. Great Plains Research 9:223-259.

Lauenroth, W. K., and O. E. Sala. 1992. Long-term forage production of North American shortgrass steppe. Ecological Applications 2:397-403.

Lauenroth, W. K., and W. C. Whitman. 1977. Dynamics of dry matter production in a mixed-grass prairie in western North Dakota. Oecologia 27:339-351.

Manley, W. A., R. H. Hart, M. J. Samuel, M. A. Smith, J. W. Waggoner, JR., and J. T. Manley. 1997. Vegetation, cattle, and economic responses to grazing strategies and pressures. Journal of Range Management 50:638-646.

Mılchunas, D. G., J. R. Forwood, and W. K. Lauenroth. 1994. Productivity of longterm grazing treatments in response to seasonal precipitation. Journal of Range Management 47:133-139.

Milchunas, D. G., and W. K. Lauenroth. 1993. Quantitative effects of grazing on vegetation and soils over a global range of environments. Ecological Monographs 63:327-366.

O'Connor, T. G., L. M. Haines, And H. A. Snyman. 2001. Influence of precipitation and species composition on phytomass of a semi-arid African grassland. Journal of Ecology 89:850-860.

Ralphs, M. H., M. M. Kothmann, and C. A. Taylor. 1990. Vegetation response to increased stocking rates in short-duration grazing. Journal of Range Management 41:483-487.

Rogers, W. M., D. R. Kirby, P. E. Nyren, B. D. Patton, and E. S. Dekeyser. 2005 Grazing intensity effects on northern plains mixed-grass prairie. The Prairie Naturalist 37:73-83.

Sala, O. E., W. J. Parton, L. A. Joyce, and W. K. Lauenroth. 1988. Primary production of the central grassland region of the United States. Ecology 69:40-45.

SAS Institute Inc. 1999. SAS/STAT user's guide. Version 8. Cary, NC: SAS Institute Inc. 1848 p.

Schuman, G. E., L. J. Ingram, P. D. Stahl, and G. F. Vance. 2005. Dynamics of longterm carbon sequestration on rangelands in the western USA. In: F. P. O'Mara, R. J. Willkins, L. 't Mannetje, D. K. Lovett, P. A. M. Rogers, and T. M. Boland [EDS.]. Proceedings of the 20th International Grassland Congress; 26 June1 July 2005; Dublin, Ireland. Wageningen, The Netherlands: Wageningen Academic Publishers. p 590.

Semmartin, M., and M. Oesterheld. 1996. Effect of grazing pattern on primary productivity. Oikos 75:431-436.

Smart, A. J., B. H. Dunn, P. S. Johnson, L. Xu, and R. N. Gates. 2007. Using weather data to explain herbage yield on three Great Plains plant communities. Rangeland Ecology \& Management 60:146-153.

Stevenson, A., R. E. Baumgartner, and G. E. Schuman. 1984. High Plains Grasslands Research Station detailed soil survey. Laramie, WY: US Department of Agriculture, Agricultural Research Service, Wyoming Agricultural Experiment Station, US Department of Agriculture, Soil Conservation Service. USDA Publication 1-84/1C/3.62. $100 \mathrm{p}$.

Teague, W. R., and S. L. Dowhower. 2003. Patch dynamics under rotational and continuous grazing management in large, heterogeneous paddocks. Journal of Arid Environments 53:211-229.

White, M. R., R. D. Pieper, G. B. Donart, and L. White Trifaro. 1991. Vegetational response to short-duration and continuous grazing in south central New Mexico. Journal of Range Management 44:399-403.

Wood, M. K., and W. H. BlackBurn. 1984. Vegetation and soil responses to cattle grazing systems in the Texas Rolling Plains. Journal of Range Management 37:303-308. 